\title{
INFLUENCE OF RRA TREATMENT ON MICROSTRUCTURE AND STRESS CORROSION CRACKING BEHAVIOR OF SPRAY FORMED 7075 ALLOY
}

\author{
RUI-MING SU, YING-DONG QU, RONG-DE LI, JUN-HUA YOU \\ School of Material Science and Engineering, Shenyang University of Technology, Shenyang, China
}

\begin{abstract}
The effects of retrogression via under pre-aging on microstructure, mechanical properties and stress corrosion cracking behavior of spray formed 7075 aluminum alloy were investigated by transmission electron microscope, tensile test and slow strain rate test. The results show that with under aging at $120^{\circ} \mathrm{C}$ for $16 \mathrm{~h}$ as pre-aging, the strength of the alloy can maintain at a high level and grain boundary precipitates are discrete after retrogression and re-aging treatment. However, retrogression treatment is uncontrollable by shortened retrogression period. After retrogression at $200^{\circ} \mathrm{C}$ for $8 \mathrm{~min}$ and re-aging, the ultimate tensile strength, elongation and SCC index of the alloy is $791 \mathrm{MPa}, 8.5 \%$ and 0.155 respectively.
\end{abstract}

Keywords: spray forming, 7075 alloy, under aging, retrogression, stress corrosion cracking, strength.

The $7075(\mathrm{Al}-\mathrm{Zn}-\mathrm{Mg}-\mathrm{Cu})$ alloys have been widely used in the aerospace industry, due to their desirable specific mechanical properties [1-4]. Until spray forming has been used on 7075 alloy in 1990s, the strengths are elevated to over $730 \mathrm{MPa}[5,6]$. Many papers have reported the effects of heat treatments on 7075 alloy which belongs to aging strengthening aluminum alloy. Silva et al. [7] and Ricker et al. [8] report that both high strength and corrosion sensibility are obtained in 7075 aluminum alloys after T6 treatment. The authors [9-11] find loss of strength of about $10 \ldots 15 \%$ after T73, T74 or T76 treatment in their studies of over-aging on corrosion resistance of 7075 alloys.

For the contradiction between strength and corrosion resistance, Cina [12] (Israel Aircraft Industries Ltd., 1974) present a three-stage treatment (retrogression and reaging, RRA). In next researches $[13,14]$ find that the strength is maintained at T6 level by RRA treatment and the stress corrosion cracking (SCC) resistance is close to T7 at the same time. Su et al. $[15,16]$ report that the RRA treatment also can improve the intergranular corrosion and exfoliation corrosion sensibility of a spray formed 7075 alloy.

The RRA treatment is divided into pre-aging, retrogression and re-aging. Ohnishi $[17,18]$ consider the peak aging to be the best pre-aging in RRA treatment process. This type of pre-aging has been used until now. In recent years, scholars report some different opinions. Lin [19] mentions that the peak aging is not a perfect pre-aging in a U.S. patent and then Han et al. [20] also discover the similar conclusion. With regard to pre-aging in RRA treatment, some arguments in the academia and studies on the type and reason of pre-aging have not been reported.

The common retrogression is always treated at high temperature for a short time, which is only dozens of seconds and even several seconds. Wu et al. [21] and Reda et al. [13] find that the sufficient retrogressed effects can be received by long-time retrogressions at a temperature below $200^{\circ} \mathrm{C}$ but the mechanical properties are lost at the same time.

Corresponding author: YING-DONG QU, e-mail: quingdong@163.com 
So to offer a data to optimize aging treatments on spray formed 7075 alloy and references for the next step research, this paper studies the retrogression on microstructure mechanical properties and SCC behavior of spray formed 7075 alloy via under aging by transmission electron microscope (TEM), tensile test and slow strain rate test (SSRT).

Experimental. The experimental material was 7075 alloy, with composition (wt.\%): $5.48 \mathrm{Zn} ; 2.21 \mathrm{Mg} ; 1.48 \mathrm{Cu} ; 0.189 \mathrm{Cr} ; 0.371 \mathrm{Fe}$ and $0.121 \mathrm{Si}$.

The technological parameters of spray forming were as follows: atomization gas was nitrogen $\left(\mathrm{N}_{2}\right)$, spray distance $-370 \ldots 380 \mathrm{~mm}$, substrate eccentricity $-60 \ldots 65 \mathrm{~mm}$, conduit bore $-3.6 \mathrm{~mm}$, angle of incidence $-37^{\circ} \ldots 39^{\circ}$, spray temperature $-770 \ldots 780^{\circ} \mathrm{C}$, crucible temperature $-735 \ldots 745^{\circ} \mathrm{C}$, horizontal velocity $-0.15 \mathrm{~mm} / \mathrm{s}$, and vertical velocity $-0.18 \mathrm{~mm} / \mathrm{s}$.

The bars after hot extrusion (temperature $-400^{\circ} \mathrm{C}$; ratio $-30: 1$; rate $-1.5 \mathrm{~mm} / \mathrm{s}$ ) were made into test samples of the diameter $12.8 \mathrm{~mm}$ for two-stage solid solution $\left(450^{\circ} \mathrm{C}\right.$ for $1 \mathrm{~h}$ and $475^{\circ} \mathrm{C}$ for $2 \mathrm{~h}$, water quenched to room temperature). Specimens were pre-aged at $120^{\circ} \mathrm{C}$ for $16 \mathrm{~h}$, retrogressed at $160 ; 200$ and $240^{\circ} \mathrm{C}$ for $\sim 4 \mathrm{~h}$, and re-aged at $120^{\circ} \mathrm{C}$ for $24 \mathrm{~h}$

SCC behaviors were tested by SCC-1 stress corrosion experimental system corresponding to international standard ISO 7539-7: 2005 (Corrosion of metals and alloys - Stress corrosion testing, Part 7: Method for slow strain rate testing), strain rate was $10^{-6} \mathrm{~s}^{-1}$ in dry air or $3.5 \mathrm{wt} . \% \mathrm{NaCl}$ solution at $35 \pm 1^{\circ} \mathrm{C}$ until cracking.

The $3 \mathrm{~mm}$ diameter disks for TEM observation were punched out directly from samples which were mechanically ground down to $60 \mu \mathrm{m}$ thickness after aging. These disks were electropolished using a DJ-2000 twin-jet electropolisher with a 30\% nitric acid solution in methanol at $-30^{\circ} \mathrm{C}$. TEM examinations were performed using a JEM2100 transmission electron microscope.

Results. Figure 1 shows the ultimate tensile strength (UTS) and conductivity of the alloy during retrogression at $160 ; 200$ and $240^{\circ} \mathrm{C}$ and corresponding re-aging. From Fig. 1, it can be seen that all tensile strength curves of retrogression decline abruptly at first, subsequently rise since falling to a certain degree, and finally declined again. Three tensile strength curves during retrogression have the similar characteristics, but the times of reaching the minimum and peak of strength are different, which depend on retrogression temperatures. Because the diffusion rate of solute and vacancy is positive correlation with retrogression temperature, it implies that the time is shortened by high retrogression temperature.

The tensile strength curves during RRA are also similar. With the retrogression time extension, the tensile strength increased firstly and then reduced after a peak value. The timing of peak strength is between the minimum and the peak of tensile strength of the retrogression curve. With the retrogression temperature increase the time of reaching peak strength is obviously shortened after RRA. The strengths are also influenced by retrogression temperature. When the samples are retrogressed at $160^{\circ} \mathrm{C}$, the peak tensile strength of the alloy after RRA is $772 \mathrm{MPa}$ (see Table). With the retrogression temperature increase, tensile strength of the alloy increases gradually. When the samples are retrogressed at $200^{\circ} \mathrm{C}$, the peak tensile strength of the alloy after RRA is $791 \mathrm{MPa}$. Then, when the retrogression temperature is increased to $240^{\circ} \mathrm{C}$, the peak tensile strength of the alloy after RRA is only $773 \mathrm{MPa}$, which is less than that via retrogression at $200^{\circ} \mathrm{C}$.

It also can be seen that the conductivities rise sharply incipiently and then gently with the retrogression time extension. The regularity of conductivities is also influenced by retrogression temperature. When the samples are retrogressed at $160^{\circ} \mathrm{C}$, the rangeability of conductivity is small. In case of the retrogression above $200^{\circ} \mathrm{C}$, the amplifi- 
cation of the conductivity is obvious. The conductivities can be improved to $40 \%$ IACS and more.
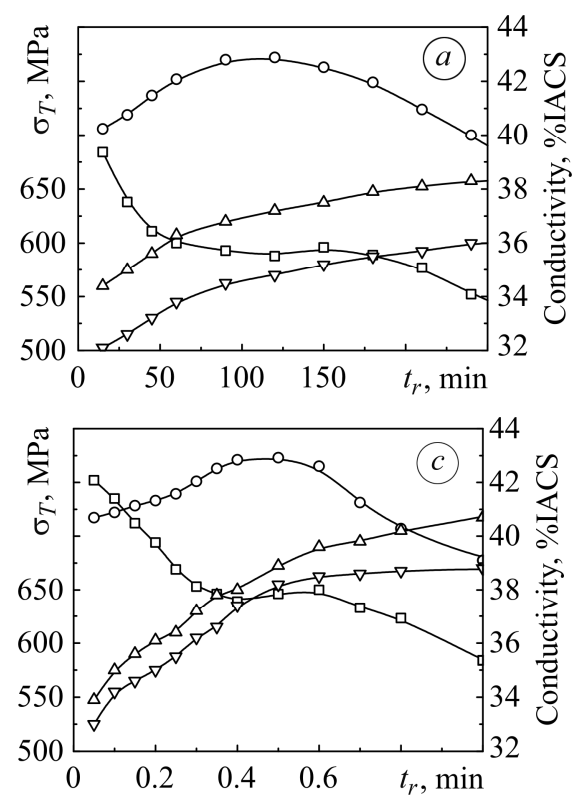

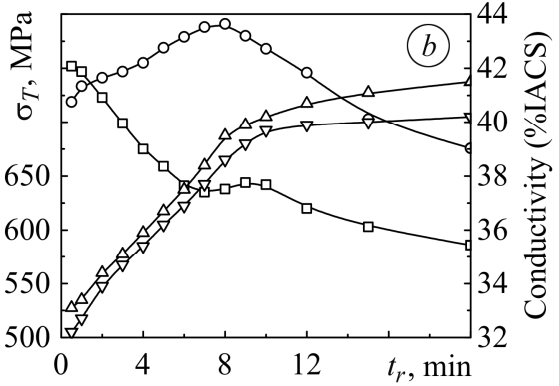

Fig. 1. Tensile strength and conductivity of the alloy during retrogression at $160^{\circ} \mathrm{C}(a)$, $200^{\circ} \mathrm{C}(b)$ and $240^{\circ} \mathrm{C}(c)$ and re-aging:

$\bigcirc, \square-$ re-aged and retrogressed strength, respectively; $\triangle, \nabla$ - re-aged and retrogressed conductivity, respectively.

Properties of the alloy after different retrogressions and re-aging treatment

\begin{tabular}{|c|c|c|c|c|c|c|c|c|}
\hline \multirow{2}{*}{$\begin{array}{l}\text { Pre- } \\
\text { aging, } \\
{ }^{\circ} \mathrm{C} \times \mathrm{h}\end{array}$} & \multirow{2}{*}{$\begin{array}{l}\text { Retrogression, } \\
{ }^{\circ} \mathrm{C} \times \min \end{array}$} & \multirow{2}{*}{$\begin{array}{l}\text { Re- } \\
\text { aging, } \\
{ }^{\circ} \mathrm{C} \times \mathrm{h}\end{array}$} & \multirow{2}{*}{$\begin{array}{c}\text { Conductivity } \\
\% \text { IACS }\end{array}$} & \multicolumn{2}{|c|}{$\begin{array}{l}\text { UTS, } \\
\mathrm{MPa}\end{array}$} & \multicolumn{2}{|c|}{$\begin{array}{c}\text { Elongation, } \\
\%\end{array}$} & \multirow{2}{*}{$I_{\mathrm{SSRT}}$} \\
\hline & & & & air & $\mathrm{NaCl}$ & air & $\mathrm{NaCl}$ & \\
\hline $120 \times 16$ & $160 \times 120$ & $120 \times 24$ & 37.2 & 772 & 710 & 8.8 & 6.6 & 0.287 \\
\hline $120 \times 16$ & $200 \times 8$ & $120 \times 24$ & 39.5 & 791 & 756 & 8.5 & 7.4 & 0.155 \\
\hline $120 \times 16$ & $240 \times 0.5$ & $120 \times 24$ & 38.8 & 773 & 737 & 8.6 & 7.7 & 0.136 \\
\hline
\end{tabular}

Figure 2 shows the stress-strain curves of SSRT in dry air and 3.5 wt. $\% \mathrm{NaCl}$ solution after three kinds of RRA treatments. From Fig. 2, it can be found that the decrements of UTSs in $\mathrm{NaCl}$ solution are similar. However, the decrements of elongations in $\mathrm{NaCl}$ solution among three kinds of RRA treatments are very different. With the retrogression at $160^{\circ} \mathrm{C}$ for $120 \mathrm{~min}$, the elongation falls down from $8.8 \%$ (in dry air) to $6.6 \%$ (in 3.5 wt.\% NaCl solution). This decrement of elongation is $25 \%$, which is far more than those for other RRA treatments with retrogression at $200^{\circ} \mathrm{C}$ and $240^{\circ} \mathrm{C}$.

To judge the SCC resistance, SCC index $I_{\text {SSRT }}$ was defined by processing various mechanical properties of SSRT.

$$
I_{\mathrm{SSRT}}=1-\frac{\sigma_{\mathrm{NaCl}} \times\left(1+\delta_{\mathrm{NaCl}}\right)}{\sigma_{\mathrm{air}} \times\left(1+\delta_{\mathrm{air}}\right)},
$$

where $\sigma_{\mathrm{NaCl}}, \sigma_{\text {air }}-$ the UTS in $3.5 \mathrm{wt} . \% \mathrm{NaCl}$ solution and in dry air (MPa), respectively; $\delta_{\mathrm{NaCl}}, \delta_{\text {air }}$ - elongation in $3.5 \mathrm{wt} . \% \mathrm{NaCl}$ solution and in dry air (\%), respectively. With the $I_{\text {SSRT }}$ close to 0 , the SCC resistance increases. SSRT properties of spray formed 7075 alloy after various RRA treatments are also listed in the Table. 

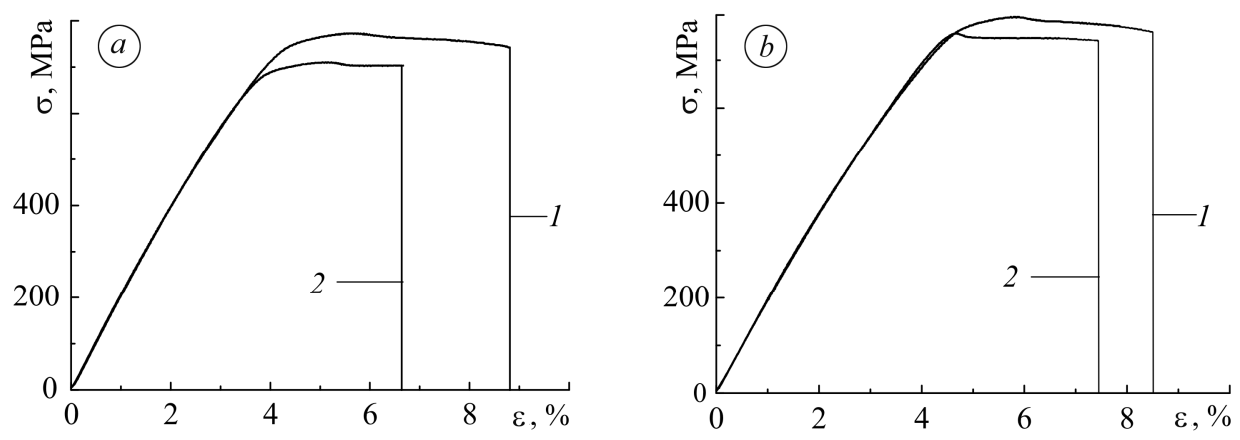

Fig. 2. SSRT Stress-strain curve of spray formed 7075 alloy with different RRA treatments: $a$ - retrogression at $160^{\circ} \mathrm{C}$ for $120 \mathrm{~min}$;

$b$ - retrogression at $200^{\circ} \mathrm{C}$ for $8 \mathrm{~min}$;

$c$ - retrogression at $240^{\circ} \mathrm{C}$ for $0.5 \mathrm{~min}$.

1 - in dry air; 2 - in 3.5 wt. $\% \mathrm{NaCl}$ solution.

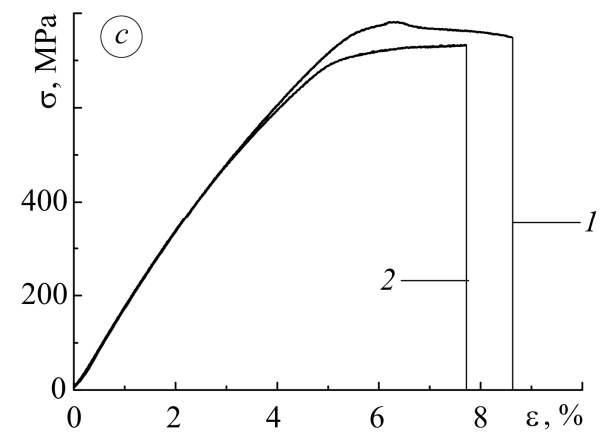

Discussion. The usual precipitation sequence of $7 \mathrm{xxx}$ series aluminum alloys can be summarized as [2]: SSS (super-saturated solid solution) $\rightarrow$ GP zones $\rightarrow$ metastable $\eta^{\prime} \rightarrow$ stable $\eta$. GP zones are metastable, coherent solute clusters of $\mathrm{Zn}, \mathrm{Mg}$ and $\mathrm{Cu}$. The metastable $\eta^{\prime}$ phases, $\mathrm{Al}, \mathrm{Cu}$ and $\mathrm{Mg}$ components based on a solid solution of $\mathrm{MgZn}_{2}$, $\mathrm{Mg}(\mathrm{ZnCuAl})_{2}$ or $\operatorname{Mg}\left(\mathrm{Zn}_{2}, \mathrm{AlMg}\right)$ appear as discrete platelet particles that are semicoherent with the matrix, which are known to populate within the grains, and $\eta$ is pseudostable, non-coherent of the same phase appearing as rods or plates, which are known to populate the grain boundary.

There is the intimate relationship between the microstructure and properties of $7 \mathrm{xxx}$ series aluminum alloys. The properties of the $7 \mathrm{xxx}$ series aluminum alloys depend on matrix precipitates (MP), grain boundary precipitates (GBP) and precipitate free zones (PFZ). According to the selected optimized heat treatment process, combination property can be obtained by cooperation of these above-mentioned three microstructures.

In microstructures the strength of the alloy mainly relies on MP. In the whole aging process, the strength of the alloy changes with the GP zone characteristic, $\eta^{\prime}$ and $\eta$. The best strength depends on thin homogeneous dispersive MP. Plasticity, toughness and SCC resistance of the alloy are remarkably influenced by structure and chemical property of GBP. There is a popular belief that continuous GBP are harmful to the alloy properties. Because relative movement of crystalline grains in deformation process has been impeded by continuous GBP, plasticity and toughness of the alloy are completely injured. On the other hand, the continuous GBP are preferentially dissolved as anodes in anodic dissolution theory. Because the potential of GBP, PFZ and matrix is $-1.05 \mathrm{~V} ;-0.85 \mathrm{~V}$ and $-0.75 \mathrm{~V}$, respectively, the potential difference (PD) between GBP and PFZ is less than the PD between GBP and matrix [22]. With regard to SCC resistance of the alloy, widening of PFZ can remit SCC sensibility and improve SCC resistance of the alloy.

Figure 3 shows the TEM images of the alloy pre-aged at $120^{\circ} \mathrm{C}$ for $16 \mathrm{~h}$ and $24 \mathrm{~h}$. From Fig. $3 a$, it can be found that the MPs are small and rare after early aging at $120^{\circ} \mathrm{C}$ for $16 \mathrm{~h}$. Because precipitation is deficient, the GBPs are small, continuous and semicontinuous. After T6 treatment $\left(120^{\circ} \mathrm{C}\right.$ for $\left.24 \mathrm{~h}\right)$, the MPs are dispersively distributed, 
most sizes are $1 \ldots 2 \mathrm{~nm}$, but some big size precipitates are more than $10 \mathrm{~nm}$, which are formed by precipitates growing during aging (Fig. 3b) GBPs are discrete, but close, like a chain. There are few PFZ at grain boundaries after pre-aging treatments. Continuous or chain-shaped GBPs are harmful to SCC resistance of the alloy, so the SCC sensibility is high in 7075 alloy for T6 treatment.
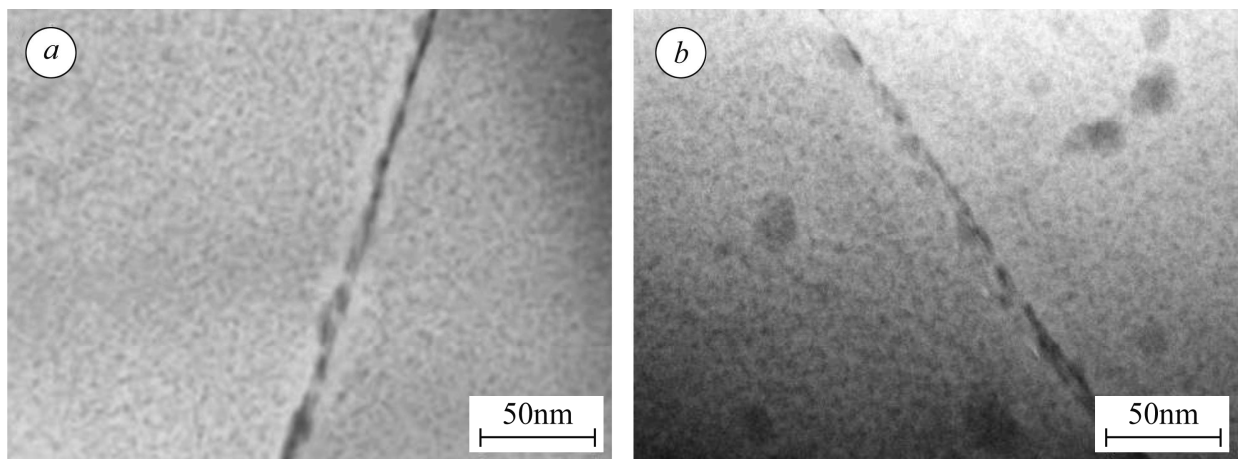

Fig. 3. TEM images of alloy pre-aged at $120^{\circ} \mathrm{C}$ for $16 \mathrm{~h}(a)$ and $24 \mathrm{~h}(b)$.

Figure 4 shows TEM images of the alloy after different retrogression and re-aging treatments. The MP are only partly redissoloved in the matrix after retrogression at a low temperature $\left(160^{\circ} \mathrm{C}\right)$ via pre-aging at $120^{\circ} \mathrm{C}$ for $16 \mathrm{~h}$, GBPs are discrete and the obvious PFZ are left at the grain boundaries (Fig. 4a). After RRA with under pre-aging and low temperature retrogression, thin homogeneous dispersive MP are separated out again in the matrix, which average sizes are less than $5 \mathrm{~nm}$. PFZ width is $15 \ldots 20 \mathrm{~nm}$.

After RRA treatment (Fig. 4b) it is because of high strength that the MP are separated out by alloy elements where lots of the MPs smaller than critical dimension are dissolved under retrogression treatment. GBPs are thick and discrete. Those GBPs can constitute an obstacle to forming the galvanic corrosions and improve corrosion resistance of the alloy. The data shows that the conductivity increases and the SCC index $I_{\text {SSRT }}$ decreases [23].

It can be seen (Fig. 4c) that most of MP have been redissolved in the matrix after retrogression at $200^{\circ} \mathrm{C}$. Parts of GBP have been redissolved, and others grow up along the grain boundaries. So the GBPs are long and discrete. After re-aging, the MPs are thin, homogeneous and dispersive and GBPs are rounded and discrete obviously. The MP size is about $2 \mathrm{~nm}$. The average size and spacing of the GBP is $5 \ldots 7 \mathrm{~nm}$ and more than $10 \mathrm{~nm}$ respectively (Fig. $4 d$ ). The SCC resistance of the alloy is improved by those discrete GBPs.

With the retrogression at $240^{\circ} \mathrm{C}$ (Fig $4 e$ ) the situation of MP mostly redissolved in matrix is similar to that after retrogression at $200^{\circ} \mathrm{C}$. But the morphology at grain boundary is different. The GBPs are semi-continuous, the sizes and spacing of the GBPs are small and some GBP are arranged side by side. After re-aging, the MPs are coarsened and grown, whose sizes increased from $1 \ldots 2 \mathrm{~nm}$ to $3 \ldots 5 \mathrm{~nm}$. The GBPs are still semi-continuous and the phenomenon of GBP arranged side by side disappeared. The PFZ are widened to $5 \mathrm{~nm}$, but they are still less narrow than at others effects of retrogression treatments, as shown in Fig. $4 f$. The SCC resistance of the alloy can be improved to a certain extent by aforementioned grain boundary structures.

The short time of retrogression at $240^{\circ} \mathrm{C}$ is the main factor of the alloy after RRA treatment effect on the properties. Because the retrogression time is only dozens of seconds, there occur the phenomena of nonuniform heat treatment of the samples, even though thin sheets. When the optimum effect has been found on the surface of the sample, the inside of the sample is uncompleted. When the inside of the sample is suited by 
retrogression, the surface of the sample has already been an overtreatment. So the strength, conductivity and SCC index $I_{\mathrm{SSRT}}$ of the alloy via retrogression at $240^{\circ} \mathrm{C}$ all are not better than that via other retrogression treatments.
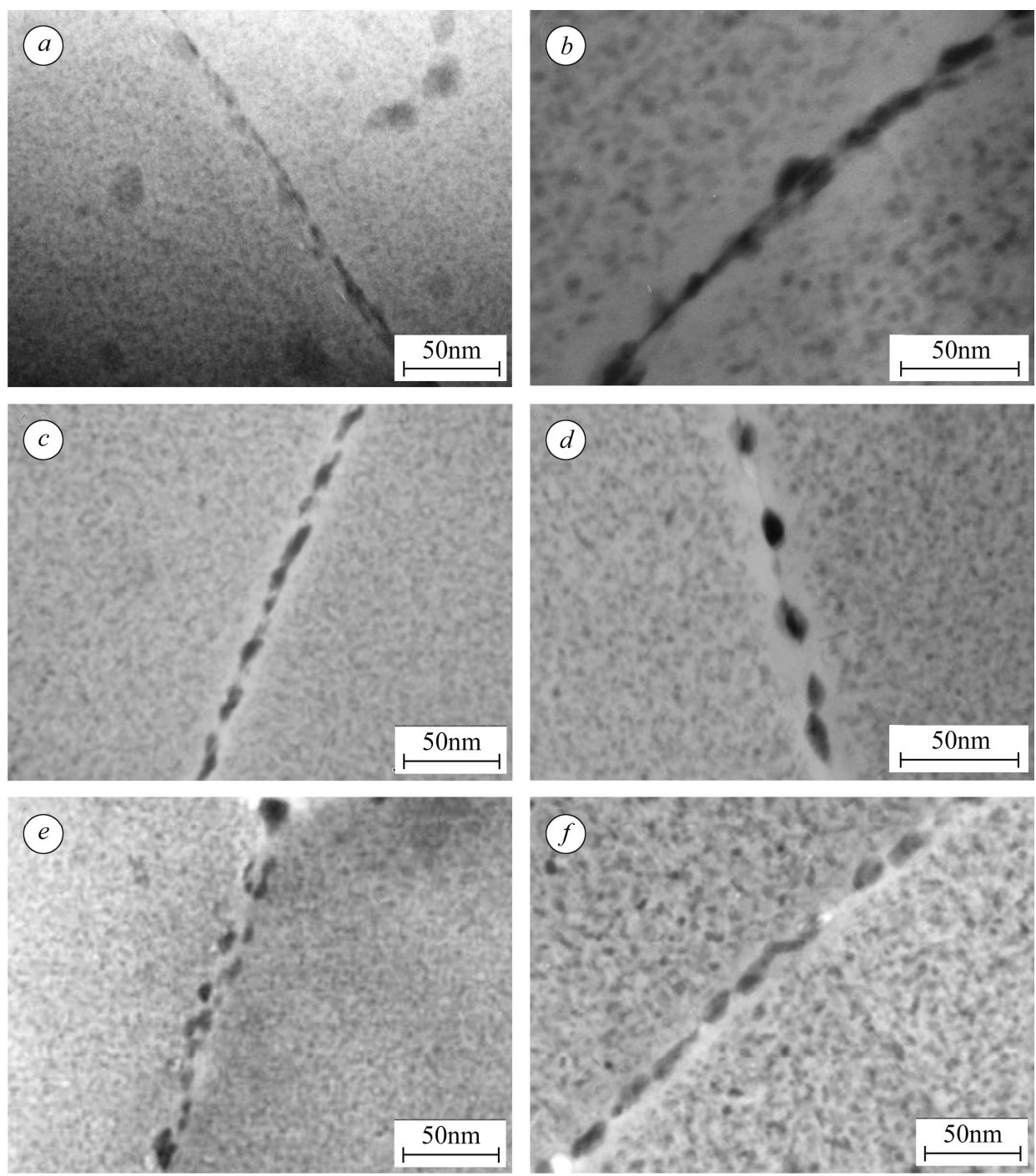

Fig. 4. TEM images of the alloy after different retrogression and re-aging treatments via under pre-aging: $a, b$ - retrogressed at $160^{\circ} \mathrm{C}$ for $120 \mathrm{~min}$ and re-aged, respectively;

$c, d$-retrogressed at $200^{\circ} \mathrm{C}$ for $8 \mathrm{~min}$ and re-aged, respectively;

$e, f$-retrogressed at $240^{\circ} \mathrm{C}$ for $0.5 \mathrm{~min}$ and re-aged, respectively.

\section{CONCLUSION}

With the under aging at $120^{\circ} \mathrm{C}$ for $16 \mathrm{~h}$ as pre-aging in RRA treatment, the following conclusions have been drawn on three retrogression treatments of spray formed 7075 alloy:

- most of the matrix precipitates (MP) are redissolved in matrix and the grain boundary precipitates (GBP) are discrete obviously after retrogression at $200^{\circ} \mathrm{C}$ for $8 \mathrm{~min}$. After re-aging, the UTS, elongation and SCC index of the alloy is $791 \mathrm{MPa}, 8.5 \%$ and 0.155 , respectively.

- MPs are only partly redissoloved in the matrix after retrogression at a low temperature $\left(160^{\circ} \mathrm{C}\right)$, the GBPs are discrete and the obvious PFZ are left at the grain 
boundaries. After RRA with low temperature retrogression, thin homogeneous dispersive MP are separated out again in the matrix, which average sizes are less than $5 \mathrm{~nm}$.

- MPs separated out of the matrix during pre-aging are effectively redissolved and GBPs are interrupted by retrogression at $240^{\circ} \mathrm{C}$, but the retrogression of the time of dozens of seconds is hardly controlled. There are some differences in the degree of treatment between the surface and inside of the sample, so the properties of the alloy after RRA are not perfect.

- the SCC index $I_{\text {SSRT }}$ is influenced by a combined action of GBP and PFZ. Continuous GBP and narrow PFZ increase the SCC susceptibility and SCC index $I_{\text {SSRT }}$ of the alloy. However, the discrete GBP and wide PFZ can improve SCC resistance and reduce SCC index $I_{\text {SSRT }}$ of the alloy.

PЕЗЮМЕ. Вивчено вплив RRA-обробки, яка полягає у витримці сплавів після штучного старіння у соляній ванні при $200^{\circ} \mathrm{C}$ і повторному штучному старінні, на мікроструктуру і механічні властивості алюмінієвого сплаву 7075. Для досліджень використано трансмісійний електронний мікроскоп. Зразки випробовували на розтяг за малої швидкості деформації. Встановлено, що після RRA-обробки вторинні частинки уздовж меж зерен виділяються дискретно. Під час такої обробки при $200^{\circ} \mathrm{C}$ упродовж $8 \mathrm{~min}$ границя міцності за розтягу, відносне видовження та коефіцієнт чутливості до корозійного розтріскування сплаву становлять $791 \mathrm{MPa}, 8,5 \%$ та 0,155 відповідно.

PЕЗЮМЕ. Изучено влияние RRA-обработки, заключающейся в выдержке сплавов после искусственного старения в соляной ванне при $200^{\circ} \mathrm{C}$ и повторном искусственном старении, на микроструктуру и механические свойства алюминиевого сплава 7075. Для исследований использован трасмиссионный електронный микроскоп. Образцы испытывали на растяжение и при малой скорости деформации. Выявлено, что после RRA-обработке вторичные частицы вдоль границ зерен выделяются дискретно. При такой бработке при $200^{\circ} \mathrm{C}$ в течение 8 min предел прочности при растяжении, относительное удлинение и коэффициент чувствительности к коррозионному растрескиванию сплава составляют $791 \mathrm{MPa}, 8,5 \%$ и 0,155 соответственно.

Acknowledgements. This research was financially supported by the Program for Liaoning Innovative Research Team in University (LT2012004) and Fok Ying-Tong Education Foundation (121054).

1. Precipitation phenomena in an ultrafine-grained $\mathrm{Al}$ alloy / T. Hu, K. Ma, T. D. Topping, J. M. Schoenung, and E. J. Lavernia // Acta Mater. - 2013. - 61. - P. 2163-2178.

2. George S. L. and Knutsen R. D. Composition segregation in semi-solid metal cast AA7075 aluminium alloy // J. Mater. Sci. - 2012. - 47. - P. 4716-4725.

3. Influence of alloy composition and heat treatment on precipitate composition in $\mathrm{Al}-\mathrm{Zn}-\mathrm{Mg}-\mathrm{Cu}$ alloys / T. Marlaud, A. Deschamps, F. Bley et al. // Acta Mater. - 2010. - 58. - P. 248-260.

4. Evolution of precipitate microstructures during the retrogression and re-ageing heat treatment of an Al-Zn-Mg-Cu alloy / T. Marlaud, A. Deschamps, F. Bley et al. // Acta Mater. - 2010. - 58. - P. 4814-4826.

5. Study of ageing treatment on spray forming Al-Zn-Mg-Cu alloy / R. M. Su, Y. D. Qu, R. X. Li, and R. D. Li // Appl. Mech. Mater. - 2012. - 217. - P. 1835-1838.

6. Jeyakumar M., Kumar S., and Gupta G. S. Microstructure and properties of the spray-formed and extruded $7075 \mathrm{Al}$ alloy // Mater. Manuf. Process. - 2010. - 25. - P. 777-785.

7. Study of the SCC behavior of 7075 aluminum alloy after one-step aging at $163^{\circ} \mathrm{C} / \mathrm{G}$. Silva, B. Rivolta, R. Gerosa, and U. Derudi // J. Mater. Eng. Perform. - 2013. - 22. - P. 210-214.

8. Chloride ion activity and susceptibility of Al alloys 7075-T6 and 5083-H131 to stress corrosion cracking / R. E. Ricker, E. U. Lee, R. Taylor et al. // Metall. Mater. Trans. A. - 2013. - 44. - P. 1353-1364.

9. The heat treatment behavior of super-high strength aluminum alloys by spray forming / G. Zhang, Z. Chen, X. Zhu et al. // J. Mater. Sci. Chem. Engng. - 2013. - 1. - P. 57-60. 
10. Fooladfar H., Hasnemi B., and Younesi M. The effect of the surface treating and hightemperature aging on the strength and SCC susceptibility of 7075 aluminum alloy // J. Mater. Engng. Perform. - 2010. - 19. - P. 852-859.

11. Comparison of SCC thresholds and environmentally assisted cracking in 7050-T7451 aluminum plate / E. M. Arnold, J. J. Schubbe, P. J. Moran, and R. A. Bayles // Ibid. - 2012. - 21. - P. 2480-2486.

12. U. S. Patent 3856584 . Reducing the susceptibility of alloys, particularly aluminium alloys, to stress corrosion cracking / B. M. Cina. - 1974.

13. Reda Y., Abdel-Karim R., and Elmahallawi I. Improvements in mechanical and stress corrosion cracking properties in Al-alloy 7075 via retrogression and re-aging // Mater. Sci. Eng. A. - 2008. - 485. - P. 468-475.

14. Influence of repetitious-RRA treatment on the strength and SCC resistance of $\mathrm{Al}-\mathrm{Zn}-\mathrm{Mg}-\mathrm{Cu}$ alloy / G. Peng, K. Chen, S. Chen, and H. Fang // Mater. Sci. Engng. A. - 2011. - 528. - P. 4014-4018.

15. Su R. M., $Q u$ Y. D., and Li R. D. Effect of aging treatments on the mechanical and corrosive behaviors of spray-formed 7075 alloy // J. Mater. Eng. Perform. - 2014. - 23. - P. 3842-3848.

16. Effect of aging treatments on microstructure and exfoliation corrosion behavior of spray forming 7075 alloy / R. M. Su, Y. D. Qu, R. D. Li et al. // Adv. Mater. Res. - 2013. - 774. - P. 872-875.

17. Ohnishi T., Ibaraki Y., and Ito T. Improvement of fracture toughness in 7475 aluminum alloy by the RRA (retrogression and re-aging) process // Mater. Trans. JIM. - 1989. - 30. - P. 601-607.

18. U. S. Patent $4713216 \mathrm{~K}$. Aluminum alloys having high strength and resistance to stress and corrosion / K. Higashi, T. Ohnishi, and I. Tsukuda. - 1987.

19. U. S. Patent 5108520J. Heat treatment of precipitation hardening alloy / J. Lin, and M. M. Kersker. - 1992.

20. Triple over-aging treatment of 7150 aluminum alloy / X. L. Han, B. Q. Xiong, Y. A. Zhang et al. // Chin. J. Nonferrous Met. - 2012. - 22. - P. 3006-3014 (in Chinese).

21. Thirty years of retrogression and re-aging (RRA) / X. J. Wu, M. D. Raizenne, R. T. Holt et al. // Canadian Aeronautics and Space Journal. - 2001. - 47, № 3. - P. 131-138.

22. Effect of aging on corrosion resistance of 7050 aluminum alloy pre-stretching plate / F. X. Song, X. M. Zhang, S. D. Liu et al. // Chin. J. Nonferrous Met. - 2013. - 23. - P. 645-651 (in Chinese).

23. Wang D., Ni D. R., and Ma Z. Y. Effect of pre-strain and two-step aging on microstructure and stress corrosion cracking of 7050 alloy // Mater. Sci. Engng. A. - 2008. - 494. - P. 360-366.

Received 17.02.2014 